\title{
INVESTIGATION OF THE EFFECT OF FLOORING ON THE LIVING PERFORMANCE OF SOWS USING SURVIVAL ANALYSIS
}

\author{
Angela Soltesz \\ Faculty of Applied Economics and Rural Development, University of Debrecen
}

\begin{abstract}
Pig-farming has a long tradition in Hungary, most significantly within the Alföld region. In my analysis I studied the lifespan of sows in two nucleus pig herds on the Great Plain, also examining the probability of the occurrence of different reasons for culling. During my research I collected data (from 2001 to 2010) relating to more than 10,000 sows from the farms conducting a breeding programme and I searched for the answer to the question of whether can I find a significant difference in the lifespan of sows with the same feeding and the same genotype if the floor type of farms is different (Herd A has a solid floor with straw and Herd B has a slatted floor). Regarding the reasons for culling ANOVA was used to investigate mean differences in logarithms of the lifespan of sows in each herd. Between the herds the seven most common culling reasons were estimated with the Kaplan-Meier method and the significant difference was demonstrated with the logrank test. The results of the log-rank test showed that there was a significant difference in leg problems as a cause of culling and deaths ( $\mathrm{p}<$ 0.05 ) between the two farms, which is the consequence of different floor types.
\end{abstract}

Keywords: lifespan of sows, floor type, culling reasons, survival analysis

\section{Introduction}

The sow replacement problem is today one of the most important challenges in sow herd management. In recent decades, the rate of sow culling has increased to levels close to 50\% per year (Dijkhuizen et al., 1989; Rodriguez-Zas et al., 2003; Patterson, 2010). The removal of nonproductive sows along with the introduction of replacement gilts is an essential part of maintaining herd productivity at a constantly high level. The reasons for culling sows and the rate of removal may be influenced by many factors (Sasaki and Koketsu, 2010) including genotype, nutrition, environment, health, behaviour, management policies and diseases (Balogh et al., 2009).

Over recent decades, genetic improvements in pigs have focused on productive traits (growth, leanness and meat quality) (Van Wijk et al., 2005; Fernández de Sevilla et al., 2008; Szabó et al., 2009). According to the herd type a $35-36 \%$ herd replacement is usually recommended. Higher replacement is necessary in nucleus herds in order to achieve a faster transfer of genetic gain (Houška, 2009).

The aim of this research was to study the lifespan of sows in two different floor type systems in the Alföld region in Hungary, also examining the probability of the occurrence of different culling reasons.

\section{Materials and methods}

This study was based on data from two commercial piglet producing herds in the Alföld region of Hungary. The genetics of the sows were Dutch Large White and Dutch Landrace crossbred. In the herds there were similar feeding but different breeding technologies. Sows were kept on solid floors in Herd A and on slatted floors in Herd B. The feed was liquid feed that was produced by the pig herds.

The source data of the sows was collected electronically with the assistance of the herd manager. The database used was from the farm-led monitoring programme KW-Röfi (an AGROCOM product). The analyses included more than 10,000 sows (3312 animals from Herd A and 6916 animals from Herd B).

The time period examined was between 2001 and 2010 . Records were treated as censored if the sow was still alive at the end of the studied period on December 31, 2010.

From the data collected we analysed the lifespan of sows according to the different culling reasons.

In the calculations, the MS Excel spreadsheet and the SPSS 17.0 statistical package were applied. In the first stage during the statistical analysis differences between culling reasons were estimated by one-way ANOVA using Tamhane's test. In the second stage Kaplan-Meier Survival Analysis (KM) was applied to calculate the significance of differences using the log-rank test.

\section{Results}

Table 1 contains the reproductive data for sows in each herd. It can be noted that Herd A had better production data. The $\mathrm{T}$ test resulted in significant differences between the two herds in all examined parameters. 
Table 1: Production parameters per sow and herd

\begin{tabular}{|c|c|c|c|c|c|}
\hline & \multicolumn{2}{|c|}{ Herd A } & \multicolumn{2}{|c|}{ Herd B } & \multirow{2}{*}{ Sig. } \\
\hline & $\overline{\mathbf{X}}$ & SD & $\overline{\mathbf{x}}$ & SD & \\
\hline $\begin{array}{l}\text { Number of } \\
\text { matings }\end{array}$ & 4.31 & 2.46 & 4.14 & 2.95 & $* *$ \\
\hline $\begin{array}{l}\text { Number of } \\
\text { weanings }\end{array}$ & 4.06 & 2.33 & 3.72 & 2.61 & $* * *$ \\
\hline $\begin{array}{l}\text { Number of } \\
\text { piglets born } \\
\text { alive }\end{array}$ & 45.38 & 28.42 & 39.42 & 29.72 & $* * *$ \\
\hline $\begin{array}{l}\text { Number of } \\
\text { piglets born } \\
\text { dead }\end{array}$ & 4.10 & 3.53 & 4.64 & 4.84 & $* * *$ \\
\hline $\begin{array}{l}\begin{array}{l}\text { Number of } \\
\text { piglets } \\
\text { weaned }\end{array} \\
\end{array}$ & 41.49 & 24.60 & 37.04 & 27.35 & $* * *$ \\
\hline
\end{tabular}

** denotes statistically significant differences at the level of $\mathrm{P} \leq 0.01$;

*** at the level of $\mathrm{P} \leq 0.001$

Source:Author's own calculation

In the period examined $68.5 \%$ of the sows were culled. Most frequently sows were culled due to leg problems (17.56\%), deaths (14.05\%), euthanasia (11.01\%), anestrus of sows $(9.14 \%)$, negative pregnancy diagnosis $(8.06 \%)$, old age $(7.00 \%)$ and return to estrus $(6.89 \%)$. Overall $30 \%$ of the culled sows were removed due to reproductive failures. For the other causes of removal the culling rate was somewhere under $5.00 \%$.

Following this I analysed the seven most frequent reasons for sow removal from the pig herds. The homogeneity test between the two herds resulted in a significant difference ( $2=113,141 ; \mathrm{df}=6$ and $\mathrm{P} \leq 0.001$ ) in terms of the reasons for the culling. Table 2 contains results of the analysis of variance (ANOVA) concerning the lifespan of sows eliminated from the herds for the most frequent reasons. In order to contrast the lifespan data with the criteria of normality the logarithm of the original data was used in the ANOVA, so the interpretability of the original data could be shown in the table.

In both herds leg problems and death on the farm are the most significant culling reasons (together the two values were about $38 \%$ in Herd A and 30\% in Herd B). Analysis showed that the cause of culling had a significant effect on the sows' lifespan. Of course the lifespan of sows was the highest if the culling occured due to old age. In Herd A apart from sows dying, those sows culled due to leg problems lived longest (the mean was 917 days) and the lifespan for sows culled due to this problem differed significantly - at the level of $\mathrm{P} \leq 0.01$ - from all other culling reasons. But there were no significant differences between the various reproductive system-related reasons for culling.

Herd B was different from Herd A. The average lifespan of sows was the highest - except for those culled due to "old age' - when sows were culled due to a negative pregnancy diagnosis (the mean was 773 days). The sows culled due to leg problems lived as long on average as sows culled due to death, euthanasia, anestrus or return to estrus.
Table 2: Lifespan depending on the most frequent causes of culling

\begin{tabular}{|c|c|c|c|c|}
\hline \multirow[b]{2}{*}{ Cause of culling } & \multicolumn{4}{|c|}{ Herd A } \\
\hline & $\mathrm{N}$ & $\begin{array}{c}\% \text { of culled } \\
\text { sows }\end{array}$ & $\overline{\mathbf{X}}$ & SD \\
\hline Leg problems & 381 & 21.3 & $917 \mathrm{~A}$ & 346 \\
\hline Death & 292 & 16.3 & $742 \mathrm{~B}$ & 344 \\
\hline Anestrus of sows & 179 & 10.0 & $582 \mathrm{C}$ & 312 \\
\hline Euthanasia & 173 & 9.7 & $703 \mathrm{~B}$ & 299 \\
\hline Return to estrus & 129 & 7.2 & $590 \mathrm{C}$ & 270 \\
\hline Old age & 120 & 6.7 & $1390 \mathrm{D}$ & 189 \\
\hline Negative pregnancy diagnosis & 52 & 2.9 & $678 \mathrm{BC}$ & 268 \\
\hline$\sum$ Other causes & 463 & 25.9 & - & - \\
\hline \multirow{2}{*}{ Cause of culling } & \multicolumn{4}{|c|}{ Herd B } \\
\hline & $\mathrm{N}$ & $\begin{array}{c}\% \text { of culled } \\
\text { sows }\end{array}$ & $\overline{\mathbf{X}}$ & $\mathrm{SD}$ \\
\hline Leg problems & 850 & 16.3 & $677 \mathrm{~A}$ & 398 \\
\hline Death & 693 & 13.3 & $658 \mathrm{~A}$ & 356 \\
\hline Euthanasia & 599 & 11.5 & $671 \mathrm{~A}$ & 349 \\
\hline Negative pregnancy diagnosis & 513 & 9.8 & $773 \mathrm{~B}$ & 370 \\
\hline Anestrus of sows & 462 & 8.8 & $688 \mathrm{~A}$ & 302 \\
\hline Old age & 371 & 7.1 & $1653 \mathrm{C}$ & 173 \\
\hline Return to estrus & 354 & 6.8 & $701 \mathrm{AB}$ & 367 \\
\hline SOther causes & 1381 & 26.4 & - & - \\
\hline
\end{tabular}

Source: Author's own calculation

Table 3 shows a comparison between the herds using survival analysis according to the seven most frequent culling risks. For all causes - with the exception of euthanasia - there were significant differences $(\mathrm{P} \leq 0.05)$ between the lifespan of the two herds. Sows culled due to leg problems in Herd A had the second

Table 3: Results of survival analysis

\begin{tabular}{|l|c|c|c|c|}
\hline \multicolumn{1}{|c|}{ Cause of culling } & $\begin{array}{c}\text { Median of } \\
\text { lifespan in } \\
\text { Herd A }\end{array}$ & $\begin{array}{c}\text { Median of } \\
\text { lifespan in } \\
\text { Herd B }\end{array}$ & $\chi 2$ & Sig. \\
\hline Leg problems & 910 & 552 & 42.965 & $* * *$ \\
\hline Death & 687 & 515 & 4.778 & $*$ \\
\hline Euthanasia & 641 & 561 & 0.135 & ns \\
\hline Old age & 1443 & 1640 & 224.281 & $* * *$ \\
\hline Anestrus of sows & 430 & 545 & 16.678 & $* * *$ \\
\hline Return to estrus & 493 & 580 & 13.481 & $* * *$ \\
\hline $\begin{array}{l}\text { Negative pregnancy } \\
\text { diagnosis }\end{array}$ & 639 & 674 & 4.790 & $*$ \\
\hline
\end{tabular}

* denotes statistically significant differences at the level of $\mathrm{P} \leq 0.05$; *** at the level of $\mathrm{P} \leq 0.001 ; \mathrm{ns}=$ not significant difference

Source: Author's own calculation 
longest lifespan (the median was 910 days) which differed significantly $(\mathrm{P} \leq 0.001)$ from the other herd. In Herd B sows culled due to reproductive causes showed greater survival rates.

\section{Discussion}

The study analysed the significant difference in the expected life-capacity of sows with similar feeding regimes and genotypes of two nucleus herds in large commercial farms in Hungary. The difference between the herds was the floor type, because Herd A had a solid floor and Herd B a slatted floor. The comparative examination is based on the causes of culling. In spite of the fact that the genetics of sows and feed technology were the same on the two examined farms there were significant differences between the lifespan of sows culled for different reasons.

Several culling factors were found to influence sow longevity, and the poor sow longevity in commercial pork production systems can lead to economic inefficiency and animal welfare concerns. In the present study reproductive problems (overall 30\%) and locomotor problems $(17.5 \%$ ) were the most important reasons for sow removals. Similar values were observed in studies from other authors. The most commonly reported reason for removals (Boyle et al., 1998; Lucia et al., 2000; Engblom et al., 2007; Szőke et al., 2009) was reproductive failure, accounting for about $30 \%$ of all removals, followed by lameness and locomotory problems (11-14\%). In several studies a higher proportion of removed sows were reported to have lameness and other locomotor problems during the periparturient period (Jorgensen, 2000; Pluym et al., 2011). Lameness is known to be a painful condition and pain may reduce feed intake.

Leg and locomotor problems in both herds examined were the most frequent reasons for culling $(21.32 \%$ on the solid floor and $16.27 \%$ on the slatted floor). There was also a significant difference between the lifespan of the culled sows. The sows kept on the solid floor stayed in production longer than those on the slatted floor. Studies which examined the prevalence of leg weakness and claw disorders on various floor types have shown that for standing slatted flooring is significantly worse than solid floors with or without straw. J $\phi$ rgensen (2003) reported that the floor types do not have the same effect on the different aspects of leg weaknesses and claw disorders. Clinical leg problems were worst on slatted floors and best in pens with straw, followed by solid floors without straw, but claw disorders are worst on solid floors without straw. KilBride et al. (2008) and Volsárová et al. (2010) also described the negative effect of slatted floors on the welfare of pigs, particularly concerning their effect on locomotive apparatus. In their study this was demonstrated by the higher mortality of pigs transported after fattening to the slaughter house from slatted floor housing compared to pigs transported from solid floor housing.

In conclusion, it can be said that the different quality of flooring (solid floors and slatted floors) had a statistically significant effect on the lifespan of sows. Sows culled due to leg problems remained in production longer in herds with solid floors than in herds with slatted floors. The productive time of sows that were removed due to death was also better on the solid floor. Based on my results, it can be stated that satisfying animal welfare conditions may contribute to sows' long term high-quality production.

\section{References}

Balogh P. - Ertsey I. - Fenyves V. - Nagy L. (2009): Analysis and optimization regarding the activity of a Hungarian Pig Sales and Purchase Cooperation. Studies in Agricultural Economics, 109: 33-54.

Boyle, L. - Leonard, F.C. - Lynch, B. - Brophy. P. (1998): Sow culling patterns and sow welfare. Irish Veterinary Journal, 51: 354-357.

Dijkhuizen, A.A. - Krabbenborg, R.M.M. - Huirne, R.B.M. (1989): Sow replacement: A comparison of farmers' actual decisions and model recommendations. Livestock Production Science, 23: 207-218.

Engblom, L. - Lundeheim, N. - Dalin, A.M. - Andersson, K. (2007): Sow removal in Swedish commercial herds. Livestock Science, 106: 76-86.

Fernández de Sevilla, X. - Fábrega, E. - Tibau, J. - Casellas, J. (2008): Effect of leg conformation on survivability of Duroc, Landrace, and Large White sows. Journal of Animal Science, 86: 2392-2400.

Houška, L. (2009): The relationship between culling rate, herd structure and production efficiency in a pig nucleus herd. Czech Journal of Animal Science, 54: 365-375.

Jørgensen, B. (2000): Longevity of breeding sows in relation to leg weakness symptoms at six months of age. Acta Veterinaria Scandinavica, 41: 105-121.

Jørgensen, B. (2003): Influence of floor type and stocking density on leg weakness, osteochondrosis and claw disorders in slaughter pigs. Animal Science, 77: 439-449.

Kilbride, A.L. - Gillman, C.E. - Ossent, P. - Green, L.J. (2008): A cross-sectional study of the prevalence and associated risk factors for capped hock and the associations with bursitis in weaner, grower and finisher pigs from 93 commercial farms in England. Preventive Veterinary Medicine, 83: 272-284.

Lucia, T. - Dial, G.D. - Marsh, W.E. (2000): Lifetime reproductive performance in female pigs having distinct reasons for removal. Livestock Production Science, 63: 213-222.

Patterson, J.L. - Beltranena, E. - Foxcroft, G.R. (2010): The effect of gilt age at first estrus and breeding on third estrus on sow body weight changes and long-term reproductive performance. Journal of Animal Science, 88: 912-938.

Pluym, L. - Van Nuffel, A. - Dewulf, J. - Cools, A. Vangroenweghe, F. - Van Hoorebeke, S. - Maes, D. (2011): Prevalence and risk factors of claw lesions and lameness in pregnant sows in two types of group housing. Preventive Veterinary Medicine, 56: 101-109.

Rodriguez-Zas, S.L. - Southey, B.R. - Knox, R.V. - Connor, J.F. - Lowe, J.F. - Roskamp, B.J. (2003): Bioeconomic evaluation of sow longevity and profitability. Journal of Animal Science, 81: 2915-2922. 
Sasaki, Y. - Koketsu, Y. (2010): Culling intervals and culling risks in four stages of the reproductive life of first service and reserviced female pigs in commercial herds. Theriogenology, 73: 587-594.

Szabó P. - Balogh P. - Komlósi I. - Kusza Sz. - Bálint A. - Bíró T. (2009): A sertéstenyésztés jövőjéről. In: Nagy J. - Jávor A. (szerk): Debreceni álláspont az agrárium jelenéről, jövőjéről. Budapest, DE-AMTC, 325-346.

Szőke Sz. - Nagy L. - Kovács S. - Balogh P. (2009): Examination of pig farm technology by computer simulation. Apstract - Applied Studies In Agribusiness And Commerce, 3: 25-30.
Van Wijk, H.J. - Arts, D.J. - Matthews, J.O. - Webster, M. Ducro, B.J. - Knol E.F. (2005): Genetic parameters for carcass composition and pork quality estimated in a commercial production chain. Journal of Animal Science, 83: 324-333.

Voslářová, E. - Chloupek, P. - Steinhauser, L. - Havlíček, J. Večerek, V. (2010): Influence of Housing System and Number of Transported Animals on Transport-induced Mortality in Slaughter Pigs. Acta Veterinaria Brno, 79: 79-84. 